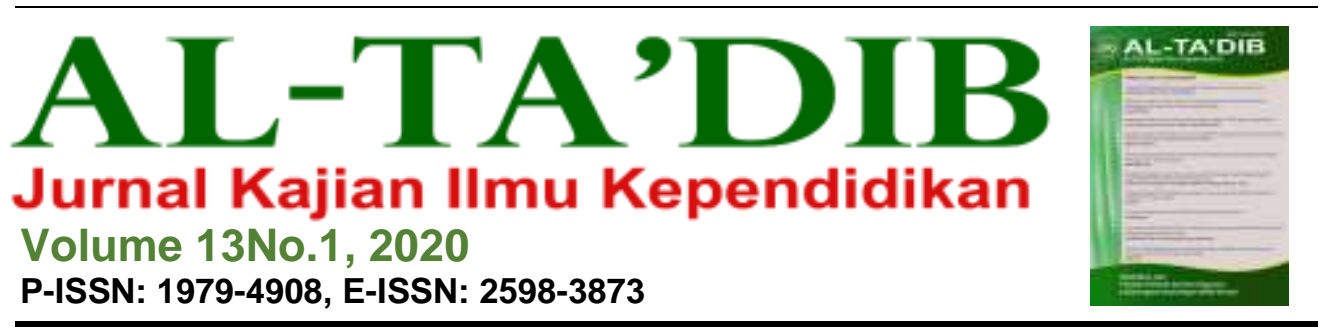

\title{
Penguasaan Keterampilan Metakognitif Mahasiswa Tadris Biologi Melalui Tugas Menulis Jurnal Belajar
}

\author{
Syarif Rizalia ${ }^{1}$; Andi Nurannisa Syam ${ }^{2}$
}

${ }^{1}$ IAIN Kendari, Indonesia;E-mail: syarifrizalia@iainkendari.ac.id

${ }^{2}$ IAIN Kendari, Indonesia;E-mail: andinurannisa@iainkendari.ac.id

\begin{tabular}{l} 
INFORMASI ARTIKEL \\
\hline Kata Kunci: \\
Jurnal belajar; \\
Keterampilan \\
Metakognitif; \\
Metacognitive Awareness \\
Inventory \\
Cara Mensitasi: \\
Rizalia, S., \& Syam. A.N., \\
(2020). Penguasaan \\
Keterampilan Metakognitif \\
Mahasiswa Tadris Biologi \\
melalui Tugas Menulis \\
Jurnal Belajar. Al-Ta'dib: \\
Jurnal Kajian Ilmu \\
Kependidikan, 13(1), 1-17 \\
DOI:
\end{tabular}

\begin{abstract}
ABSTRAK
Penelitian ini bertujuan untuk mengetahui dampak pemberian tugas menulis jurnal belajar terhadap penguasaan keterampilan metakognitif mahasiswa. Sampel penelitian adalah 31 mahasiswa semester lima pada program studi Tadris Biologi. Mereka dibagi ke dalam dua kelompok: kelompok 1 menggunakan strategi menulis jurnal belajar, dan kelompok 2 tidak menggunakan strategi menulis jurnal belajar. Indikator penelitian ini adalah skor yang diperoleh mahasiswa pada lembar inventory Metacognitive Awareness Inventory (MAI) dan SEMLI-S pada masing-masing kategori keterampilan metakognitif yaitu merencanakan, memonitoring, dan mengevaluasi. Hasil penelitian menunjukkan bahwa keterampilan metakognitif kelompok 1 lebih tinggi dibanding kelompok 2, dengan nilai signifikansi yang lebih kecil dibanding nilai a sehingga dapat disimpulkan bahwa ada perbedaan penguasaan keterampilan metakognitif yang signifikan antara kelompok 1 dan kelompok 2.
\end{abstract}




\begin{tabular}{l} 
ARTICLE INFO \\
\hline Keywords: \\
Learning Journal; \\
Metacognitive Awareness \\
Inventory; Metacognitive \\
Skill \\
How to cite: \\
Rizalia, S., \& Syam. A.N., \\
(2020). Penguasaan \\
Keterampilan Metakognitif \\
Mahasiswa Tadris Biologi \\
melalui Tugas Menulis \\
Jurnal Belajar. Al-Ta'dib: \\
Jurnal Kajian Ilmu \\
Kependidikan, 13(1), 1-17 \\
DOI:
\end{tabular}

\begin{abstract}
The aim of this study is to determine the effect learning journal writing to students' metacognitive skills. Focusing on 31fifth-semester students majoring in biology education, they weregrouped into two: group 1 with learning journal writing strategy, and group 2 without learning journal writing strategy. Indicators of this study are students scores ofupon completing the Metacognitive Awareness Inventory (MAI) and SEMLI-S inventory sheets in metacognitive skills category, i.e. planning, monitoring, and evaluating. The results indicated that group 1 metacognitive skills were higher than group 2, with a significance valuesmaller than the $\alpha$ value.This study shows that there were significant differences in the mastery of metacognitive skills between the groups.
\end{abstract}

\section{Pendahuluan}

Kurikulum Kerangka Kualifikasi Nasional Indonesia (KKNI) memunculkan banyak harapan adanya perbaikan mutu pendidikan, khususnya pada peningkatan kualitas pembelajaran. Tolak ukur adanya peningkatan kualitas pembelajaran adalah pencapaian tujuan pembelajaran secara optimal, yang dapat dijadikan sebagai indikator bahwa tujuan pembelajaran yang disyaratkan dalam mata kuliah telah tercapai. Pencapaian tujuan pembelajaran mahasiswa selama proses pembelajaran berbeda antara satu mahasiswa dengan mahasiswa lainnya (van Velzen, 2016). Perbedaan ini disebabkan oleh banyak faktor, baik langsung maupun tidak langsung yang dapat mempengaruhi keberhasilan mahasiswa dalam memahami materi pelajaran. Salah satu faktor yang mempengaruhi adalah dosen yang kurang inovatif dalam mengembangkan perangkat pembelajaran. Dalam kegiatan pembelajaran, masih banyak dosen yang cenderung hanya mementingkan hasil yang akan diperoleh mahasiswa tanpa memperhatikan proses atau bagaimana hasil itu diperoleh.

Beberapa model perangkat pembelajaran hasil buatan dosen belum merujuk pada analisis kebutuhan mahasiswa. Perangkat pembelajaran yang dimaksudkan adalah mengangkat materi kuliah yang berada di lingkungan mahasiswa (kontekstual). Dalam konteks pembelajaran, kontekstual bermakna mencontohkan konsep-konsep yang tidak awam bagi mahasiswa akan tetapi konsep tersebut sudah menjadi prior knowledge mahasiswa namun belum terstruktur dengan baik dalam memori mereka sehingga mahasiswa dapat mengubah elaborasi proses berpikirnya, yaitu dapat 
berpikir secara deduksi-induksi, atau induksi-deduksi, dan menggali potensi diri sehingga dapat memaknai arti belajar pada tingkat individu untuk mencapai tujuan pembelajaran yang ditetapkan. Menurut Setiawan \& Setiawan (2020), proses pembelajaran hanya mengembangkan aspek kognitif namun jarang memberdayakan kemampuan metakognitif. Selain itu, dalam mengajar dosen lebih dominan dan jarang mengaplikasikan model-model pembelajaran yang sudah ada. Hal ini ditunjukkan dengan masih cukup rendahnya nilai metakognitif mahasiswa, dari skor maksimal 56 rerata nilai yang diperoleh 23. Masalah ini menjadi tantangan bagi dosen dalam memberdayakan metakognitif mahasiswa.

Metakognitif merupakan suatu kemampuan mengkontruksi pemikirannya secara kompleks (Soto, de Blume, Jaconiva, McNamara, Benson, \& Riffo, 2019). Metakognitif juga merupakan kemampuan yang harus diberdayakan dan dikembangkan di jenjang pendidikan tinggi (van Velzen, 2016). Hal ini perlu dilakukan karena metakognitif dapat membantu mengembangkan kemampuan mahasiswa dalam menentukan keputusan yang cermat, sistematis, logis, serta tepat (Setiawan, Corebima, \& Zubaidah, 2013). Selain itu kemampuan metakognitif merupakan kemampuan yang mendukung empat pilar pendidikan yaitu learning to know, learning to do, learning to be, dan learning to live together (Zubaidah, 2016).

Masalah pengembangan metakognitif juga terjadi di IAIN Kendari, khususnya pada Program Studi Tadris Biologi yang secara umum belum jelas memperlihatkan adanya implementasi keterampilan metakognitif dalam proses pembelajaran. Hal ini berdasarkan observasi awal, bahwa dosen umumnya menggunakan model pembelajaran yang bervariasi (bergantiganti) untuk meningkatkan pemahaman konsep biologi pada mahasiswa, namun belum ada upaya yang signifikan untuk memberdayakan keterampilan metakognitif mahasiswa baik secara langsung maupun melalui media perangkat pembelajaran. Pemberdayaan keterampilan metakognitif dapat meningkatkan strategi kognitif atau ada korelasi yang signifikan antara keterampilan metakognitif dengan strategi kognitif (Cetinkaya \& Erktin, 2002).

Metakognitif dapat dimanfaatkan untuk menerapkan pola pikir pada situasi lain yang dihadapi. Strategi metakognitif pada diri mahasiswa dapat dilakukan dalam empat tahapan proses, yaitu perencanaan diri (selfplanning), pemonitoran diri (self-monitoring), evaluasi diri (self-evaluating), dan refleksi diri (self-reflecting) (Yukselturk \& Bulut, 2005). Namun, untuk dapat mengembangkan keterampilan metakognitif mahasiswa maka 
sebaiknya diterapkan dalam bentuk pendekatan, model, maupun strategi pembelajaran (Jahidin, 2008).

Salah satu strategi yang dapat meningkatkan keterampilan metakognitif adalah menggunakan jurnal belajar (Corebima \& Idrus, 2006). Jurnal belajar merupakan catatan refleksi mahasiswa selama proses pembelajaran yang berisi materi yang telah dipahami, yang belum dipahami, dan yang perlu dipelajari lebih lanjut demi mencapai tujuan pembelajaran. Jurnal bukan ringkasan materi pembelajaran, tetapi lebih kepada refleksi diri dan hasil pemikirannya terhadap materi yang telah dipelajari (Sabilu, 2009).

Jurnal belajar yang dituliskan mahasiswa meliputi pengalaman belajar, materi yang telah dipahami dan materi yang belum dipahami dengan menyebutkan alasan dan kendalanya serta mengemukakan cara atau usaha yang akan dilakukan untuk mengatasinya. Menurut Nurhadi dan Senduk (2004), dengan jurnal belajar mahasiswa dapat mengetahui kelemahan dan kelebihan dirinya. Mahasiswa membutuhkan pemahaman terhadap kekuatan dan kelemahannya untuk menata tujuan yang diinginkan dan membangun strategi untuk mencapai tujuan tersebut. Menurut Sadikin, Aina, dan Hakim (2016), jurnal belajar dapat dipakai sebagai salah satu alat penilaian yang bersifat autentik. Melalui jurnal belajar dosen dapat menilai seberapa dalam pemahaman mahasiswa terhadap materi yang baru dipelajari, sekaligus mengoreksi kelemahan dan kesalahan mahasiswa dalam memahami materi kuliah. Jurnal belajar dapat dijadikan dosen sebagai refleksi mengenai pembelajaran yang telah dilakukan dengan merujuk pada kemajuan yang dicapai mahasiswa dari hasil refleksinya (Nurfaidah, Lengkanawati, \& Sukyadi, 2017).

Penelitian terdahulu tentang pengembangan metakognitif di dalam ruang belajar hanya berfokus pada pembelajaran umum dimana dosen selalu menjadi trendsetter dalam kegiatan pembelajaran, namun belum melibatkan mahasiswa secara total dalam memahami kemampuan berpikir dan menyelesaikan semua masalah pembelajaran yang diberikan padanya. Salah satu penelitian yang dilakukan Setiawan dan Setiawan (2020) fokus pada memberdayakan metakognitif mahasiswa melalui model pembelajaran jinemam. Selain itu, penelitian Septiyana, Prasetyo dan Christijanti (2013) menemukan bahwa jurnal belajar dan strategi berpikir metakognitif memiliki korelasi yang signifikan terhadap hasil belajar siswa tingka sekolah menengah atas. Namun, hasil peneitian mereka belum dapat dikatakan sebagai hasil yang representatif karena sampel penelitian hanya dilakukan di satu kelas dan satu sekolah saja, sehingga penulis berinisiatif untuk mencoba menerapkan strategi pembelajaran tersebut di lingkungan lokal. Oleh karena 
itu, penelitian ini bertujuan untuk melihat dampak pemberian tugas menulis jurnal belajar terhadap penguasaan keterampilan metakognitif mahasiswa, khususnya mahasiswa program studi tadris biologi, IAIN Kendari.

\section{Metode Penelitian}

Jenis penelitian ini adalah penelitian eksperimen semu (quasi experiment), karena eksperimen yang dilakukan menggunakan objek manusia sebagai sampel penelitian. Objek tersebut tidak dapat dikendalikan (dikontrol secara total) karena mereka memiliki akal untuk berbuat/melakukan suatu kegiatan, sehingga kecenderungan variabel error lebih besar terjadi. Eksperimen yang dimaksud adalah untuk mengetahui ada tidaknya perbedaan keterampilan metakognitif mahasiswa akibat pemberian tugas menulis jurnal belajar. Desain penelitian ini adalah desain penelitian post-test non equivalen control group design.

Variabel yang terdapat dalam penelitian ini yaitu tugas menulis jurnal belajar yang merupakan variabel bebas, dan keterampilan metakognitif yang merupakan variabel terikat. Dalam penelitian ini jurnal belajar mencakup rekaman tertulis tentang apa yang telah dipelajari mahasiswa, yang digunakan untuk meringkas topik-topik kunci yang dipelajari, misalnya perasaan mahasiswa terhadap kegiatan pembelajaran, kesulitan yang dialami, atau keberhasilan didalam memecahkan masalah atau topik tertentu, komentar yang dibuat oleh mahasiswa, yang diberikan pada setiap akhir pembelajaran.Variabel lainnya adalah keterampilan metakognitif yaitu taktik dan strategi yang dipikirkan oleh pelajar agar mereka dapat meningkatkan hasil belajarnya dengan mengorganisir/merencanakan, memonitor, dan mengevaluasi aktivitas belajarnya, yang diukur dengan menggunakan lembar Metacognitive Awareness Inventory (MAI) yang diberikan pada akhir pembelajaran. Indikator dalam penelitian ini adalah skor yang diperoleh mahasiswa pada lembar MAI dan Self-Efficacy and Metacognition Learning Inventory-Science (SEMLI-S) pada masing-masing indikator keterampilan metakognitif, dengan standar nilai 0-5 pada rating scale (Jahidin, 2008).

Populasi pada penelitian ini yaitu seluruh mahasiswa semester lima kelas A Program Studi Tadris Biologi, IAIN Kendari, tahun akademik 2019/2020. Penentuan sampel penelitian dengan teknik purposive sampling yaitu dengan mengambil dua kelompok besar yang memiliki kemampuan akademik relatif sama (dilihat dari nilai akademik di pertemuan-pertemuan sebelumnya) dan yang sedang memprogramkan mata kuliah kurikulum pendidikan biologi sehingga diperoleh kelompok percobaan, yaitu kelompok 1 sebanyak 16 orang (menggunakan jurnal belajar dalam kegiatan 
pembelajarannya) dan kelompok 2 sebanyak 15 orang (tidak menggunakan jurnal belajar dalam kegiatan pembelajarannya).

Instrumen penelitian ini terdiri atas instrumen tes keterampilan metakognitif menggunakan inventori yang diadaptasi dari MAI dan SEMLIS (Jahidin, 2012), dan rating scale keterampilan metakognitif yang dapat dilihat pada Tabel 1 .

Tabel 1. Rating Scale Keterampilan Metakognitif

\begin{tabular}{ll}
\hline 0 & Belum mengenal metakognitif. \\
Belum & \\
\hline 1 & $\begin{array}{l}\text { Muncul tapi belum memiliki kesadaran berpikir sebagai suatu } \\
\text { proses. }\end{array}$ \\
\hline 2 & $\begin{array}{l}\text { Mampu memisahkan apa yang dipikirkan dengan bagaimana ia } \\
\text { berpikir }\end{array}$ \\
\hline 3 Belum benar & $\begin{array}{l}\text { Dapat membantu kesadaran berpikir sendiri jika didorong dan } \\
\text { didukung. }\end{array}$ \\
Mulai & \\
berkembang & Menyadari pemikiran sendiri dan dapat membedakan input dan \\
\hline & $\begin{array}{l}\text { output fase pemikiran sendiri. Terkadang menggunakan model } \\
\text { ini untuk mengatur pemikiran sendiri dan belajar. }\end{array}$ \\
\hline 5 & $\begin{array}{l}\text { Menggunakan kesadaran metakognitif secara teratur untuk } \\
\text { mengelola pikiran sendiri dan belajar. Menyadari berbagai } \\
\text { kemungkinan pemikiran, dapat menggunakannya dengan lancar } \\
\text { untuk merefleksikan proses ini. }\end{array}$ \\
\hline
\end{tabular}

Konversi nilai rating scale terhadap skor hasil kerja LKS adalah:

0 : Jika tidak ada penyelesaian tugas dalam LKS

$1:$ Jika skor LKS antara $0-20$

2 : Jika skor LKS antara $21-40$

3 : Jika skor LKS antara $41-60$

4 : Jika skor LKS antara $61-80$

5 : Jika skor LKS antara $81-100$

Penelitian ini melalui prosedur dalam pengumpulan data. Pertama, peneliti melakukan observasi awal untuk mengidentifikasi masalah pembelajaran biologi pada mahasiswa semester lima kelas A Program Studi Tadris Biologi, IAIN Kendari. Kedua, peneliti menetapkan alternatif tindakan untuk mengatasi masalah yang dihadapi yaitu dengan penerapan pembelajaran biologi berbasis tugas jurnal belajar pada mata kuliah kurikulum pendidikan biologi. Ketiga, peneliti membuat perencanaan/skenario pembelajaran sesuai dengan tahap-tahap pembelajaran biologi berbasis tugas jurnal belajar. Keempat, peneliti mengembangkan format pengamatan pembelajaran. Kelima, peneliti melaksanakan kegiatan 
pembelajaran dengan penerapan pembelajaran biologi berbasis tugas jurnal belajar sesuai dengan RPS yang telah dirancang oleh peneliti. Lalu pada setiap akhir materi diadakan evaluasi dengan memberi post-test dan angket dalam bentuk inventory untuk mengukur keterampilan metakognitif mahasiswa. Terakhir, mengolah data untuk mengetahui penguasaan konsep dan pemberdayaan keterampilan metakognitif mahasiswa.

Terkait jurnal belajar, ada beberapa tahapan dalam pembuatannya. Pertama, siswa mengisi identitas diri. Setelah itu, siswa menjawab beberapa pertanyaan sebagai berikut: a) Bagaimana menurut Anda kegiatan pembelajaran yang dilaksanakan hari ini?; b) Hal-hal baru apa saja yang Anda peroleh melalui kegiatan hari ini?; c) Catatlah hal-hal penting dari apa yang Anda dapatkan!; d) Adakah materi yang belum Anda pahami dari materi pembelajaran hari ini?; e) Bagaimana cara/usaha yang akan Anda lakukan untuk mempelajari materi yang belum dipahami?; f) Lainnya. Adapun rubrik penilaian jurnal belajar dapat dilihat pada Tabel 2 berikut.

Tabel 2. Rubrik Penilaian Jurnal Belajar

Kriteria Penilaian Jurnal Belajar Skor

1. Hari dan Tanggal

Hari dan tanggal menulis jurnal belajar sesuai dengan saat pembelajaran berlangsung

2. Pengalaman Belajar

a. Menceritakan pengalaman belajar di kelas yang mencakup jalannya pembelajaran di kelas

b. Menceritakan hal-hal yang berkesan saat belajar

3. Materi yang Telah Dipahami

a. Menyebutkan materi yang telah dipahami

b. Menjelaskan/merangkum materi yang telah dipahami

4. Materi yang Belum Dipahami

a. Menyebutkan materi yang belum dipahami

b. Menjelaskan alasan/kendala dalam memahami materi tersebut

c. Mengemukakan cara/usaha yang akan dilakukan untuk memahami materi tersebut 
Data dalam penelitian ini dianalisis dengan menggunakan aplikasi software SPSS 23.0 untuk mengetahui statistik deskriptif dan inferensial. Analisis deskriptif digunakan untuk menggambarkan data penelitian dalam bentuk mean (rata-rata), standar deviasi, dan presentase. Sedangkan analisis inferensial digunakan untuk menguji hipotesis melalui uji t-test, tetapi sebelumnyaterlebih dahulu dilakukan uji normalitas data hasil penelitian dan homogenitas varians kelompok data.

\section{Hasil dan Pembahasan}

\subsection{Hasil Analisis Statistik Deskriptif}

\section{Distribusi Nilai Keterampilan Metakognitif}

Nilai keterampilan metakognitif kelompok 1 berkisar antara 2.20 sampai 3.96 dengan rata-rata nilai 2.90. Sedangkan nilai keterampilan metakognitif mahasiswa pada kelompok 2 berkisar 2.41 sampai 3.27 dengan rata-rata nilai 2.87. Deskripsi nilai keterampilan metakognitif dapat dilihat pada Tabel 3.

Tabel 3 Deskripsi Nilai Keterampilan Metakognitif Kelompok 1 dan Kelompok 2

\begin{tabular}{cccc}
\hline & Deskripsi & K.Metac Kelompok & K.Metac Kelompok \\
& Valid & 1 & 2 \\
\hline \multirow{2}{*}{$\mathrm{N}$} & Missing & 16 & 15 \\
& Mean & 0 & 0 \\
& Median & 2.90 & 2.87 \\
Mode & 2.93 & 2.84 \\
& $2.65(\mathrm{a})$ & $2.72(\mathrm{a})$ \\
& Std. Deviation (SD) & .34 & .19 \\
\hline
\end{tabular}

Tabel 3 menjelaskan bahwa banyak data yang valid pada variabel kelompok $1=16$, kelompok $2=15$, dengan $\mathrm{N}$ Missing 0 . Hal ini menandakan bahwa dari variabel di atas, tidak ada data yang hilang atau tidak dimasukkan dalam analisis frekuensi. Selain itu, diketahui bahwa keterampilan metakognitif kelompok 1 dan kelompok 2 memiliki variasi nilai sebagai berikut: nilai tengah (median) 2.93 untuk kelompok 1 dan 2.84 untuk kelompok 2, nilai yang sering muncul (modus) 2.65 untuk kelompok 1 dan 2.72 untuk kelompok 2, nilai deviasi standar (penyimpangan/bias) yang diperoleh yaitu 0.34 dan 0.12 untuk kelompok 1, serta 0.19 untuk kelompok 2. Hal ini menandakan bahwa dari kumpulan data di atas, kelompok 2 memiliki nilai yang tidak terlalu bias karena nilai yang diperoleh lebih mendekati nol (titik normal data) dibanding kelompok 1. 


\section{Distribusi Nilai Jurnal Belajar Kelompok 1}

Nilai jurnal belajar kelompok 1 berkisar antara 38 sampai 92 dengan rata-rata nilai 56.50. Deskripsi nilai jurnal belajar dapat dilihat pada Tabel 4.

Tabel 4. Deskripsi Nilai Jurnal Belajar Kelompok 1

\begin{tabular}{ccc}
\hline \multirow{2}{*}{$\mathrm{N}$} & Valid & 16 \\
\cline { 2 - 3 } & \multicolumn{1}{c}{ Missing } & 0 \\
\hline & Mean & 56.50 \\
Median & 54.60 \\
Mode & $44.00(\mathrm{a})$ \\
& Std. Deviation & 11.04 \\
\hline
\end{tabular}

Tabel 4 menjelaskan bahwa banyak data yang valid pada variabel 16 dengan N Missing 0 . Hal ini menandakan bahwa dari variabel di atas, tidak ada data yang hilang atau tidak dimasukkan dalam analisis frekuensi. Selain itu diketahui bahwa jurnal belajar mahasiswa kelompok 1 memiliki variasi nilai sebagai berikut: nilai tengah (median) 54.6, nilai yang sering muncul (modus) 44, nilai deviasi standar (penyimpangan/bias) yang diperoleh dari data di atas yaitu 11,04 .

\subsection{Hasil Analisis Statistik Inferensial}

\section{Uji Normalitas Data}

Uji normalitas yang digunakan dalam analisis data penelitian ini yaitu melalui analisa grafik P-Plot. Dimana pada grafik akan nampak titik-titik bulat yang merupakan simbol dari nilai-nilai dari tiap distribusi. Selanjutnya, titik-titik bulat tersebut akan berada di sekitar garis normal. Jika titik-titik tersebut mendekati garis normal, maka diasumsikan bahwa data berdistribusi normal, begitu pula sebaliknya (Kadir, 2012). Grafik P-Plot dapat dilihat pada Gambar 1. 


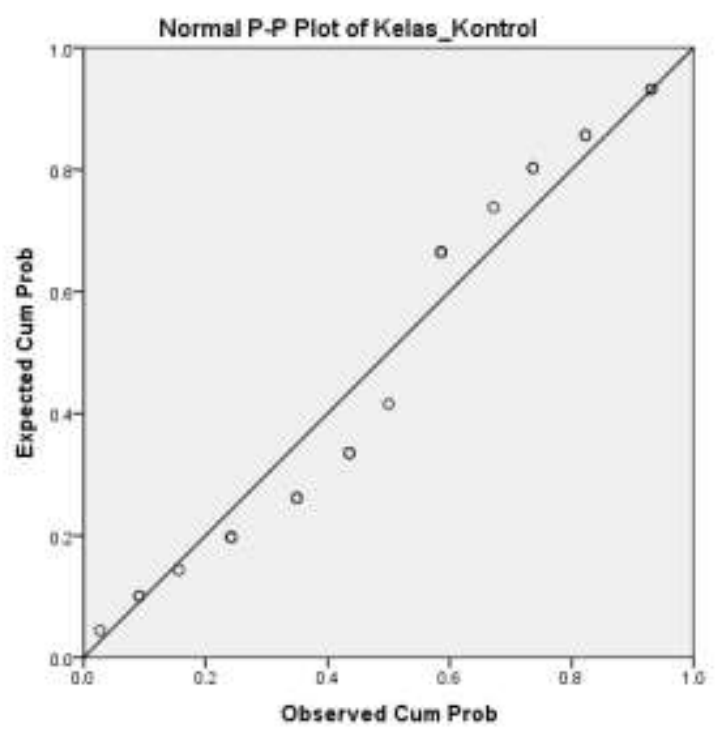

Gambar 1 Grafik P-Plot Uji Normalitas Data

Berdasarkan grafik tersebut diketahui bahwa nilai-nilai dari tiap distribusi di atas berdistribusi normal karena semua titik mendekati garis normal, dan uji homogenitas dapat dilanjutkan.

\section{Uji Signifikansi Koefisien Korelasi}

Koefisien korelasi dimaksudkan untuk mencari hubungan antarvariabel, yaitu variabel bebas (independent) dan variabel terikat (dependent). Besarnya koefisien menggambarkan seberapa erat hubungan linear antara dua peubah. Perubahan yang terlibat kedua-duanya bertipe numerik dan menyebar normal jika ingin pengujian terhadapnya bersifat sah.

Berdasarkan hasil analisis diketahui bahwa korelasi antara jurnal belajar dan keterampilan metakognitif tidak signifikan. Hal ini dikarenakan nilai signifikansi perolehannya lebih besar dari nilai $\alpha$ sehingga dapat dikatakan bahwa jika nilai variabel bebasnya (jurnal belajar) tinggi, maka nilai variabel terikatnya (keterampilan metakognitif) rendah. Untuk lebih jelasnya, nilai signifikansi dari setiap variabel dapat dilihat pada Tabel 5.

Tabel 5 Nilai Signifikansi Korelasi Tiap Variabel Penelitian

\begin{tabular}{cccc}
\hline Variabel & Nilai Signifikansi & Nilai $\alpha$ & Keterangan \\
\hline Jurnal Belajar dan & 0,99 & 0,05 & Tidak Signifikan \\
Keterampilan & & & \\
Metakognitif & & & \\
\hline
\end{tabular}




\section{Uji Homogenitas dan Hipotesis Varians Data}

Uji homogenitas dan hipotesis varians data penelitian ini menggunakan uji independent sample test karena kedua jenis sampel tidak berikatan (berhubungan) atau saling bebas. Artinya, kejadian yang ada pada sampel satu belum tentu terjadi pada sampel dua. Kriteria uji homogenitas dari independent sample test yaitu menerima $\mathrm{H}_{0}$ jika nilai signifikansi lebih besar dari nilai $\alpha(0,05)$, begitu pula sebaliknya. Berdasarkan analisis data

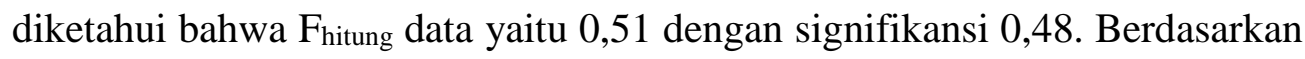
kriteria uji maka dapat dikatakan bahwa $\mathrm{H}_{0}$ diterima karena nilai signifikansinya $(0,48)$ lebih besar dibanding nilai $\alpha(0,05)$. Artinya data kedua kelompok mempunyai varians yang homogen $\left(\mathrm{S}_{1}{ }^{2}=\mathrm{S}_{2}{ }^{2}\right)$, dan uji hipotesis dapat dilanjutkan.

Kriteria uji hipotesis dari independent sample test yaitu menerima $\mathrm{H}_{0}$ jika nilai signifikansi data lebih besar dari nilai $\alpha(0,05)$, dan menolak $\mathrm{H}_{0}$ jika nilai signifikansi data lebih kecil dari nilai $\alpha(0,05)$. Berdasarkan analisis data diketahui bahwa thitung data yaitu 2,11 dengan signifikansi 0,04. Berdasarkan kriteria uji maka dapat dikatakan bahwa $\mathrm{H}_{0}$ ditolak karena nilai signifikansinya $(0,04)$ lebih kecil dibanding nilai $\alpha(0,05)$. Artinya ada perbedaan keterampilan metakognitif yang diajar melalui tugas menulis jurnal belajar dengan yang diajar tanpa melalui pemberian tugas menulis jurnal belajar.

Tabel 6. Uji Homogenitas dan Hipotesis Data

\begin{tabular}{cccccc}
\hline Nilai & \multicolumn{2}{c}{ Hasil Uji F } & Hasil Uji t & $\alpha$ \\
\hline Keterampilan & F Fitung & Signifikansi & thitung & Signifikansi & \\
Metakognitif & 0.51 & 0.48 & 2,11 & 0,04 & 0,05 \\
Keterangan & \multicolumn{2}{c}{ Varians homogen } & & $\mathrm{H}_{0}$ ditolak & \\
\hline
\end{tabular}

Pada bagian pembahasan ini diuraikan tentang keterampilan metakognitif melalui tugas menulis jurnal belajar yang ditinjau lembar inventory yang telah diadaptasi. Ada tiga komponen keterampilan metakognitif, yaitu merencanakan (planning), memonitor (monitoring), dan mengevaluasi (evaluating). Merencanakan (planning) seperti menentukan tujuan dan analisis tugas membantu mengaktivasi pengetahuan yang relevan sehingga mempermudah pengorganisasian dan pemahaman materi pelajaran. Memonitor (monitoring) dapat membantu mahasiswa memahami materi dan mengintegrasikannya dengan pengetahuan awal melalui aktivitas membaca dan membuat pertanyaan atau pengujian diri. Mengevaluasi (evaluating)adalah suatu proses belajar yang meliputi penilaian kemajuan aktivitas belajar. Kemampuan mengevaluasi dalam konteks metakognitif 
adalah pertimbangan seseorang tentang kemampuan dan keterbatasannya (Lee \& Baylor, 2006).

\section{Keterampilan Metakognitif pada Tahap Merencanakan (Planning)}

Implementasi suatu strategi pembelajaran akan melibatkan seluruh mahasiswa secara aktif dalam kegiatan pembelajaran. Mahasiswa mengkonstruk cara berpikirnya untuk memunculkan strategi kognitif ketika belajar atau mengaplikasikan pengetahuannya dalam proses pembelajaran. Hal ini sejalan dengan pendapat Slavin (2005) yang menyatakan bahwa dalam proses pembelajaran mahasiswa harus terlibat aktif dan menjadi pusat kegiatan belajar dan pembelajaran di kelas. Planning yang matang akan menciptakan kebiasaan mahasiswa dalam belajar dan menjadi pebelajar mandiri sehingga dengan atau tanpa suatu strategi belajar apapun mahasiswa akan mampu mengoptimalkan pembelajaran jika sudah merencanakannya dengan baik (Slavin, 2005).

Selanjutnya, proses memfungsikan keterampilan berkomunikasi dan beargumen tidak terlepas dari prinsip-prinsip yang terdapat dalam keterampilan metakognitif yaitu merencanakan, manajemen informasi, dan mengevaluasi belajar mahasiswa sehingga berperan aktif dalam proses merencanakan belajarnya. Peters (2000) berpendapat bahwa keterampilan metakognitif memungkinkan mahasiswa berkembang sebagai pebelajar mandiri, karena didorong menjadi penilai atas perencanaannya sendiri (Peters, 2000). Hal ini didukung oleh Weinstein dan Meyer (1986) yang menyatakan bahwa sebuah strategi pembelajaran kognitif merupakan suatu perencanaan untuk mengarahkan sumber daya kognitif seperti perhatian dan informasi jangka panjang untuk membantu tujuan belajar mahasiswa. Planning merefleksi aksi rangkaian belajar diperlukan untuk mencapai tujuan belajar mahasiswa dan menetapkan tujuan utama belajar (Jahidin, 2008).

\section{Keterampilan Metakognitif pada Tahap Memonitoring (Monitoring)}

Potensi suatu strategi pembelajaran kooperatif dalam mengembangkan keterampilan metakognitif tahap monitoring didukung oleh pendapat Koriat, Goldsmith dan Pansky (2000) yang mengemukakan bahwa aspek penting dalam metcognitive regulation adalah kemampuan mahasiswa untuk mengingat kembali dan pantauan realitas memori, setelah mengingat kepastian jawaban, mahasiswa dapat memonitor apakah jawaban benar atau salah atau dengan kata lain, mahasiswa dapat menilai apakah informasi yang 
muncul dari memori relevan dengan peristiwa yang dikehendaki atau diingat (Jahidin, 2008).

Model pembelajaran kooperatif berpengaruh nyata terhadap kemampuan untuk memantau proses dan aktivitas belajar mahasiswa. Hal ini sejalan dengan esensi teori konstruktivisme yaitu dalam proses belajar di kelas, mahasiswa harus menemukan dan mentransfer suatu masukan informasi kompleks ke situasi lain. Dengan kata lain, memonitor daya ingat/pikiran sangat diperlukan untuk mendapatkan hasil belajar yang baik.

\section{Keterampilan Metakognitif pada Tahap Evaluating}

Potensi tugas menulis jurnal belajar terhadap keterampilan metakognitif tahap evaluating menjadikan mahasiswa mampu menilai hasil pekerjaannya, mengidentifikasi proses selanjutnya dan memahami tujuan belajar. Selama proses ini, mahasiswa sanggup mengidentifikasi kekuatan, dimana terjadi kelemahan yang tersisa dan mengembangkan sebuah rencana untuk memperbaiki tingkat pemahamannya. Oleh sebab itu, mahasiswa dapat mengevaluasi kelemahan dalam proses belajar, dan tanpa disadari mereka telah memanfaatkan dan mengembangkan keterampilan metakognitif.

Setelah mengetahui keterampilan metakognitif di tiga tahap, maka diperoleh nilai rerata dari ketiga tahap tersebut. Nilai rerata inilah yang menjadi patokan perbandingan keterampilan metakognitif di kedua kelompok eksperimen. Pada kelompok 1, keterampilan metakognitif mahasiswa secara klasikal memperoleh rerata 2.9, dan 2.87 di kelompok 2. Berdasarkan hal tersebut dapat dikatakan bahwa keterampilan metakognitif di kelompok 1 lebih baik dibanding keterampilan metakognitif di kelompok 2.

Kelemahan yang menyebabkan belum tercapainya penguasaan keterampilan metakognisi mahasiswa di kelompok 2 adalah seorang mahasiswa tidak terbiasa mengevaluasi materi. Beberapa penelitian menunjukkan, jika mahasiswa diberi kesempatan dan latihan untuk mengembangkan kemampuan metakognitif, maka mahasiswa akan menjadi penyelesai soal yang baik karena menjadi mampu mengidentifikasi proses berpikirnya untuk menyelesaikan tugas yang diberikan.

Selanjutnya pemberian tugas menulis jurnal belajar juga sangat berpengaruh terhadap keterampilan metakognitif mahasiswa. Menurut Thorpe (2004) jurnal belajar bermanfaat bagi mahasiswa dalam membantu pengembangan kemampuan merefleksi dan introspeksi diri. Refleksi dan introspeksi diri terjadi saat menulis dimana mahasiswa mencatat dan mengilustrasikan semua pengalamannya. Hal ini membantu mahasiswa 
mensintesis dan menerjemahkan pikiran dan perilaku dalam bentuk tulisan, simbol atau grafik, dapat memilih strategi berpikir yang tepat, serta dapat mengetahui kelemahan dan kelebihan atas tindakan yang diambil (Sabilu, 2009).

Nurhadi dan Senduk (2004) menyatakan bahwa dengan jurnal belajar mahasiswa mengetahui kelemahan dan kelebihan dirinya, yang merupakan suatu modal dasar untuk belajar. Mahasiswa membutuhkan pemahaman terhadap kekuatan dan kelemahannya untuk menata tujuan yang diinginkan dan membangun strategi untuk mencapai tujuan tersebut. Sabilu (2009) menjelaskan bahwa salah satu strategi metakognitif dasar adalah menghubungkan informasi baru dengan pengetahuan terdahulu. Dengan begitu mahasiswa merasa memperoleh sesuatu yang berguna bagi dirinya tentang apa yang baru dipelajarinya. Oleh karena itu, keterampilan metakognitif kelompok 1 secara klasikal lebih baik dibanding keterampilan metakognitif di kelompok 2.

Selanjutnya, hal lain yang menjadi acuan dalam penelitian ini yaitu penggunaan jurnal belajar di kelompok 1. Berdasarkan hasil analisis data, diketahui bahwa penggunaan jurnal belajar mengalami peningkatan nilai ditiap pertemuan yang dapat dilihat pada rerata perolehan nilai tiap mahasiswa dari pertemuan 1 sampai pertemuan 5. Hal ini memberikan pengaruh yang baik terhadap keterampilan metakognitif di kelompok tersebut. Dimana diketahui bahwa kelompok 1 memiliki nilai yang lebih baik dibanding kelompok 2 yang ditinjau dari kedua variabel tersebut.

Hal ini sejalan dengan penelitian Sabilu (2009) yang menyatakan bahwa penggunaan jurnal belajar memberikan pengaruh yang signifikan terhadap kemampuan metakognitif mahasiswa dalam belajar biologi, dimana kelas yang menggunakan pembelajaran multistrategi dengan jurnal belajar memperoleh nilai rerata 74.23 dan kelas yang menggunakan pembelajaran multistrategi tanpa jurnal belajar memperoleh nilai rerata 64.18 (Sabilu, 2009).

Selain itu, perlu diketahui bahwa bentuk atau format jurnal belajar yang dikembangkan dalam penelitian ini adalah menggabungkan antara jurnal metakognisi dan jurnal refleksi. Kedua bentuk ini berpotensi dalam mengembangkan metakognitif mahasiswa. Septiyana, dkk (2013) menjelaskan bahwa metakonitif dapat didefinisikan sebagai berpikir tentang berpikir dan pemonitoran pemprosesan kognitif. Jurnal belajar merupakan salah satu bentuk konkrit yang bisa dibuat untuk mengaplikasikan metakognitif. Selanjutnya, Pillow (2008) menyatakan bahwa jurnal refleksi 
merupakan alat yang membantu mempromosikan pembelajaran aktif (active learning) pada mahasiswa.

\section{Kesimpulan}

Berdasarkan hasil dan pembahasan, dapat disimpulkan bahwa tugas menulis jurnal belajar berpengaruh terhadap keterampilan metakognitif mahasiswa, yang dibuktikan dengan nilai inventory kelompok 1 dan kelompok 2. Secara klasikal, keterampilan metakognisi kelompok 1 (dengan pemberian jurnal belajar) sebesar 2.9 dan kelompok 2 (tanpa pemberian jurnal belajar) sebesar 2.87.

Selanjutnya diharapkan kepada dosen pengampu mata kuliah kurikulum pendidikan biologi untuk menerapkan pemberian tugas menulis jurnal belajar karena terbukti secara statistik mampu memberikan pengaruh yang baik terhadap keterampilan metakognisi mahasiswa.

\section{Ucapan Terima Kasih}

Penulis mengucapkan terima kasih kepada mahasiswa(i) semester lima kelas A program studi Tadris Biologi IAIN Kendari, atas kerja samanya dalam melakukan quasi eksperimen ini.

\section{Daftar Pustaka}

Cetinkaya, P., \& Erktin, E. (2002). Assessment of metacognition and to relationship with reading comprehension, achievement, and aptitude. Boğaziçi Üniversitesi Eğitim Dergisi. 19(1), 1-11.

Corebima, A. D., \& Idrus, A. A. (2006). Pemberdayaan dan pengukuran kemampuan berpikir pada pembelajaran biologi (empowerment and measurement of thinking skill in biology learning). In International Conference and Measurement and Evaluation in Education, School of Educational Studies UniversitiSains Malaysia Penang, Malaysia. Vol. 103.

Nur, M., \& Ibrahim, M. (2011). Pembelajaran Berdasarkan Masalah. Surabaya: PSMS Unesa.

Jahidin. (2008). Pemahaman guru-guru biologi SMAN Bau-Bau tentang keterampilan metakognitif dan strategi kooperatif STAD \& CIRC. Bioedukasi: Jurnal Biologi dan Pembelajaran. 1(2): 126-139. 
Jahidin. (2010). Pengaruh strategi pembelajaran M3K (reading, identification, and examine of concept) dan konvensional terhadap keterampilan metakognisi dan penguasaan konsep biologi. Jurnal Gema Pendidikan. 17(2): 28-35.

Jahidin. (2012). Pemberdayaan keterampilan metakognisi berbasis pembelajaran kontekstual serta hubungannya dengan penguasaan konsep biologi. Jurnal MIPA. 11(1): 38-47.

Kadir. (2012). Statistika Pendidikan. Kendari: Universitas Haluoleo.

Koriat, A., Goldsmith, M., \& Pansky, A. (2000). Toward a psychology of memory accuracy. Annual Review of Psychology. 51(1): 481-537.

Lee, M. \& Baylor, A. L.. (2006). Designing metacognitive maps for webbased learning. Educational Technology \& Society. 9(1): 344-348.

Nurhadi, B. Y., \& Senduk, A. G. (2004). Pembelajaran kontekstual dan penerapannya dalam KBK. Malang: Universitas Negeri Malang Press.

Nurfaidah, S., Lengkanawati, N. S., \& Sukyadi, D. (2017). Levels of reflection in EFL pre-service teachers' teaching journal. Indonesian Journal of Applied Linguistics. 7(1): 80-92.

Peters, M. (2000). Does constructivist epistemology have a place in nurseeducation?. Journal of Nursing Education. 39(4): 166-172.

Pillow B. (2008). Development of children's understanding of cognitive activities. Journal of Genetic Psychology. 169(4): 297-321.

Sabilu, M. (2009). Pengaruh penggunaan jurnal belajar dalam pembelajaran multi strategi terhadap kemampuan kognitif dan metakognitif siswa SMA Negeri 9 Malang. Tesis. Malang: Universitas Malang.

Sadikin, A., Aina, M., \& Hakim, N. (2016). Penerapan asesmen berbasis portofolio dan jurnal belajar untuk meningkatkan kemampuan metakognitif dan motivasi belajar mahasiswa pada mata kuliah Perencanaan Pengajaran Biologi. BIODIK. 2(2): 50-61.

Septiyana, K., Prasetyo, A. P. B., \& Christijanti, W. (2013). Jurnal belajar sebagai strategi berpikir metakognitif pada pembelajaran Sistem Imunitas. Journal of Biology Education. 2(1): 1-9. 
Setiawan, D. C., Corebima, A. D., \& Zubaidah, S. (2013). Pengaruh strategi pembelajaran reciprocal teaching (RT) dipadu pemberdayaan berpikir melalui pertanyaan (PBMP) terhadap kemampuan metakognitif biologi siswa SMA Islam Al-Ma'arif Singosari Malang. Proceeding Biology Education Conference: Biology, Science, Environmental, and Learning. 10(2): 195-201.

Setiawan, D. C., \& Setiawan, D. (2020). Pemberdayaan metakognitif mahasiswa melalui model pembelajaran jinemam. Edubiotik: Jurnal Pendidikan, Biologi dan Terapan. 5(01): 11-17.

Slavin, R. E. (2005). Cooperative Learning: Teori, Riset dan Praktik (Penjmh. Narulita Yusron). Bandung: Nusa Media.

Soto, C., de Blume, A. P. G., Jacovina, M., McNamara, D., Benson, N., \& Riffo, B. (2019). Reading comprehension and metacognition: The importance of inferential skills. Cogent Education. 6(1): 1-20. Doi.org/10.1080/2331186x.2019.1565067

Thorpe, K. (2004). Reflective learning journals: From concept topractice. Reflective Practice. 5(3): 327-343.

van Velzen, J. (2016). Metacognitive Learning: Advancing Learning by Developing General Knowledge of The Learning Process. London: Springer.

Weinstein, C. E., \& Mayer, R. E. (1986). The teaching of learning strategies. Handbook of Research on Teaching. Vol. 3: 315-327.

Yukselturk, E., \& Bulut, S. (2005). Relationships among self-regulated learning components, motivational beliefs and computer programming achievement in an online learning environment. Meditteranean Journal of Educational Science.

Zubaidah, S. (2016). Keterampilan abad ke-21: Keterampilan yang diajarkan melalui pembelajaran. Dalam Seminar Nasional Pendidikan, Juni, 1-17. https://doi.org/10.1021/acs.langmuir.6b02842. 